\title{
Seasonal changes in frequency of diseases in dab, Limanda limanda, from the southern North Sea
}

\author{
B.-G. Wolthaus \\ Institut für Meeresforschung Bremerhaven; Am Handelshafen 12, D-2850 Bremerhaven, \\ Federal Republic of Germany
}

\begin{abstract}
Infestation rates of flatfish Limanda limanda from the southern North Sea (German Bight) were investigated in 1981 and 1982. At three stations, including a dumping area of acid-iron wastes northwest of Helgoland, dabs were examined for the occurrence of lymphocystis and epidermal papillomas. Marked seasonal changes of infestation rates were observed with maxima of diseased fish in March and May (epidermal papillomas $2 \%$ in 1981, $4.1 \%$ in 1982; lymphocystis $7.5 \%$ in 1981, $17.2 \%$ in 1982). Infestation minima were found from June to October. Differences in incidence rates were observed between stations in winter and spring, but not in summer. Both diseases turned out to be size-dependent. Seasonality of the two diseases is discussed in relation to spawning cycle and water quality, including pollution.
\end{abstract}

\section{INTRODUCTION}

In recent years, numerous reports have been published which indicate an increase of certain fish diseases in polluted coastal waters as compared to less polluted areas of the open sea. A number of authors propose a relationship between frequencies of fish diseases and environmental pollution (see review by Sindermann, 1980).

Dethlefsen \& Watermann (1980) reported on the high prevalence of epidermal papilloma in dab from the German Bight on a dumping ground for wastes originating from titanium dioxide production. The results were questioned by Möller (1981) who investigated the occurrence and abundance of diseases in the German Bight and in Danish coastal areas during August 1980. He found low infestation rates for epidermal papilloma and for lymphocystis. The obvious differences between these two investigations suggested a possible seasonal fluctuation in the occurrence of the diseases under consideration.

This investigation presents information on the seasonal fluctuations of diseases in dab Limanda limanda at the dumping ground for titanium dioxide wastes and compares the rates of disease occurrence with those obtained from adjacent areas. The study is part of a current program on diseases of North Sea fishes carried out jointly by several German research institutions. The study was designed to reveal seasonal changes in (a) general infestation rates of dab with lymphocystis and epidermal papilloma, (b) abundance of dab, (c) length distribution of dab, (d) intensity of infestation of diseased fish and (e) sex ratio. It was hoped that the data obtained would provide insight into the 


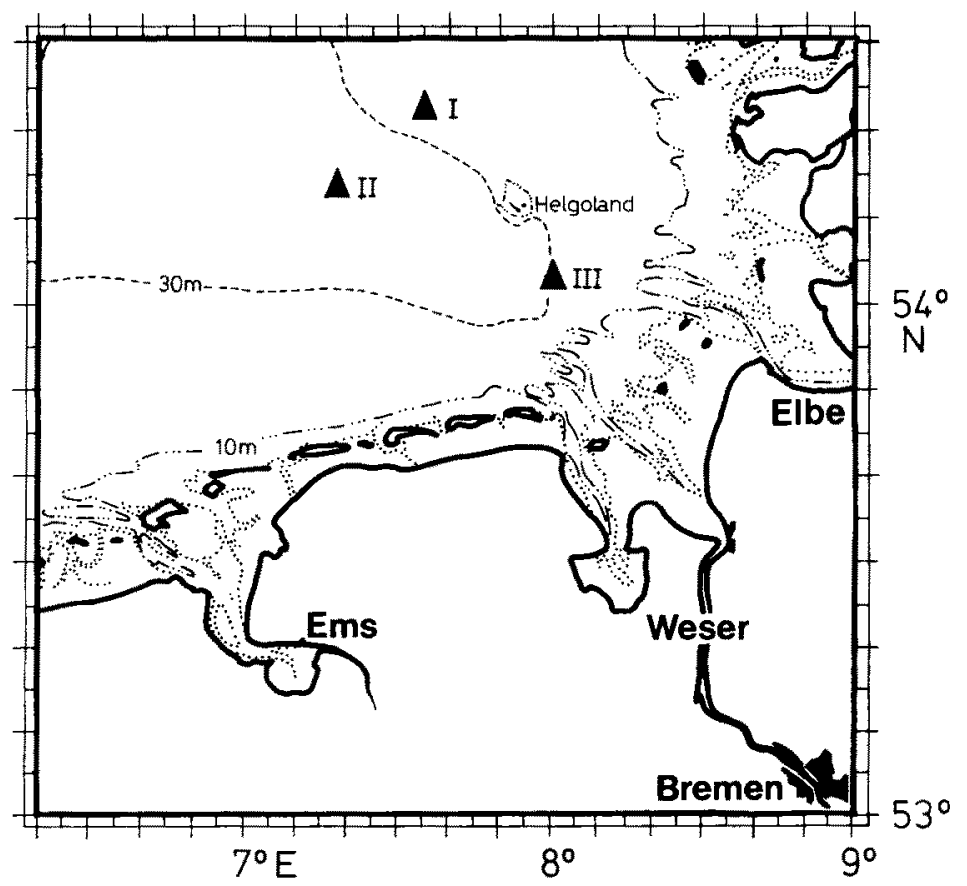

Fig. 1. Location of Stations I, II and III in the German Bight (North Sea)

differences between sampling sites; relations between body length and infestation rate; variation of infection rates with sex s $_{i}$ and differences of sex ratios between stations.

\section{MATERIAL AND METHODS}

\section{Station}

Three stations were selected for comparative purposes (Fig. 1). Station I was located in the centre of a dumping area for wastes from titanium dioxide production. This area has been used to dump up to $4500 \mathrm{t}$ of acid iron wastes per day, amounting to $750000 \mathrm{t} / \mathrm{yr}$ since 1969. Station II was located west, Station III southeast of Helgoland. The geographical coordinates of the three stations are: Station I $54^{\circ} 22.6^{\prime} \mathrm{N}, 07^{\circ} 35.5^{\prime} \mathrm{E}_{i}$ Station II $54^{\circ} 13.0^{\prime} \mathrm{N}, 07^{\circ} 20.0^{\prime} \mathrm{E}$; Station III $54^{\circ} 02.5^{\prime} \mathrm{N}, 08^{\circ} 0.0^{\prime} \mathrm{E}$. At Station I ( $25 \mathrm{~m}$ depth) the bottom consisted of fine and medium sand. At Station II ( $35 \mathrm{~m}$ ) muddy very fine sand prevailed, and at Station III $(23 \mathrm{~m})$ the bottom was muddy. Monthly sampling by RV "Victor Hensen" was carried out from February to November 1981; in 1982, samples were taken in February, March, May, August and October. Six consecutive bottom trawls were performed per station and month. The bottom trawl used had a mesh size of $120 \mathrm{~mm}, 370$ meshes in total; the cod end had a mesh size of $20 \mathrm{~mm}$. Trawling time was $30 \mathrm{~min}$; towing speed was $3-3.5$ knots. The length of the rope was $150 \mathrm{~m}$ at Station $\mathrm{I}$, $175 \mathrm{~m}$ at Station II and $150 \mathrm{~m}$ at Station III. 


\section{Materials}

Immediately after the catch, dab were weighed (total wet weight), measured (total length to $\mathrm{cm}$ below), sexed and investigated for externally visible diseases. Location and intensity of the diseases were also recorded. Intensities of lymphocystis and epidermal papillomas were arbitrarily grouped in different stages. In lymphocystis, Group A represented only singular nodules, Group B showed medium and Group C heavy infection. Sizes of epidermal papillomas were classified into 4 groups, corresponding to the surface of dab covered by papilloma. The diseased surface area was estimated by cutting out patterns of dab of all $\mathrm{cm}$ groups and patterns of all measured papilloma sizes in pasteboard.

Subsequently, the patterns were weighed. Using these weights the surface covered by papillomas was calculated and grouped: $\mathrm{A}<0.5 \% ; 0.5 \%<\mathrm{B}<1.0 \% ; 1.0 \%<\mathrm{C}<$ $1.5 \% ; 1.5 \%<D$. Significant variability in infestation rate among hauls (Dethlefsen et al., 1983) was also found during this study (hauls taken on the same day at the same station). Whenever possible, results from 6 hauls per station were pooled. Age of dab was calculated according to Bohl (1957).

\section{Statistics}

To avoid biases due to different fish lengths, infestation rates were related to a population of standardized size according to Bishop et al. (1975). For determination of the influence of length, month, area, population density and infestation rate, use was made of the quantal response model (Lindner \& Berchtold, 1976). To list whether single factors, e.g. station, exert any influence on infestation rates, the method proposed by Bishop et al. (1975) for testing likelihoods was used.

\section{RESULTS}

\section{Abundance and length distribution of dab}

Generally, dab were most abundant at Station I during the 2 years of investigation (Fig. 2). Only in February 1981 were dab most abundant at Station II, and in May, June

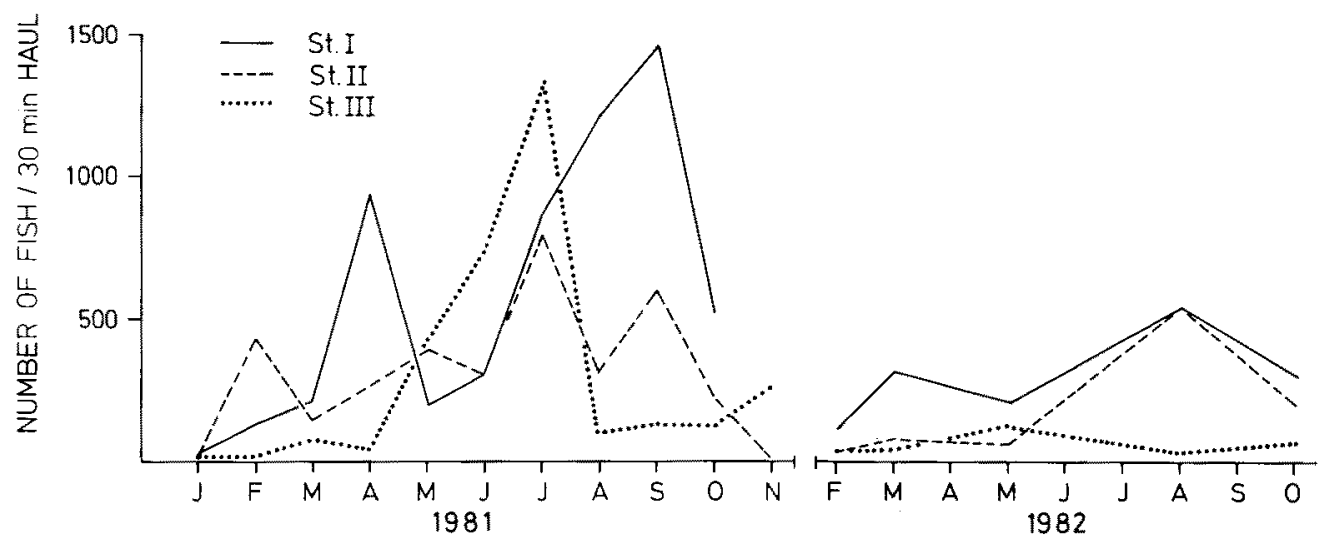

Fig. 2. Limanda limanda. Relative abundance, expressed as number of dab caught per $30 \mathrm{~min}$ trawling time (mean value based on 6 hauls); Stations I, II and III 


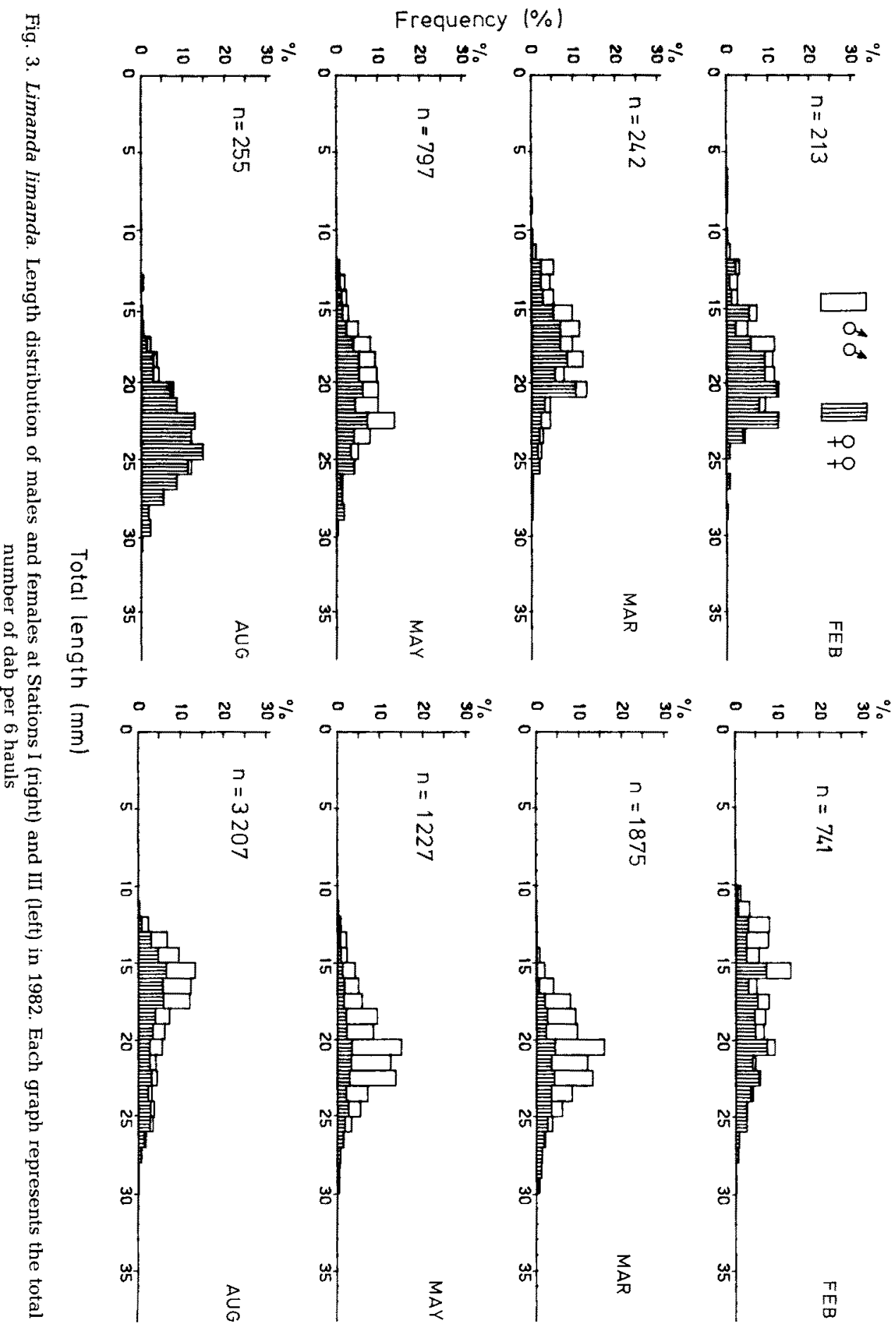


and July 1981 at Station III. Except for these months in 1981, lower numbers of dab were found at Station III than at I and II. In 1982 also, highest frequencies of dab were found at Station I. Only in August 1982 were maximum numbers encountered at Station II. Again, lowest dab numbers were caught at Station III. In 1981 and 1982, there were considerable changes in the length distribution between months and stations. There was also a difference in sex ratios between stations: more females were caught, especially in summer, at the onshore Station III (Fig. 3).

Seasonal changes in infestation rate and intensity of lymphocystis and epidermal papillomas

Due to the similarities between the results on lymphocystis and epidermal papillomas, both diseases will be treated in this section (Table 1). In 1981 and 1982, highest infestation rates of both dab diseases were found in February, March and May. Thereafter, infestation rates decreased rapidly at all stations. Between July and October infestation rates remained low.

Highest infestation rates for lymphocystis were found in the dumping area followed by Stations II and III from February to June 1981. From July to October no differences in infestation rate of dab with lymphocystis were detected among the 3 stations under investigation. The same general seasonal fluctuation pattern of infestation rate was found in 1982; only in March was the infestation rate of dab from Station II higher than that at Station III.

In both diseases, the infestation rates showed higher values from February to May in 1982 than in 1981 at all stations. In August and October the low levels of infestation rates in both diseases were similar to those in 1981. In 1981 and 1982, no significant differences in infestation rates of both diseases were found between males and females.

In general, the highest infestation rates were found near the dumping area in all samples taken. The only exception was in March 1982, when infestation rates at Station II were higher than those for dab from the dumping area. Lowest infestation rates were generally found at Station III.

The majority of diseased dab showed lesions of lymphocystis or of epidermal papilloma of intensities $A$ and $B$ throughout the whole year (Tables 2, 3). In winter and spring, more heavily diseased fish with lymphocystis (Stage C) and epidermal papilloma (Stages $C$ and D) were found than in summer and autumn. In summer and autumn, the intensity of both diseases decreased and the percentage of dab with initial disease stages increased.

\section{Correlation between body length and infestation rate}

Due to the variability in length distribution of dab, it was necessary to calculate the correlation between length of fish and infestation rate. In both sexes for both diseases, the infestation rates increased with increasing body length (Table 4). This result was consistent for the whole period under survey. The smallest dab with lymphocystis was $12 \mathrm{~cm}$ ( 2 years old), that with epidermal papilloma $16 \mathrm{~cm}$ ( 3 years old). The highest infestation rates were found, in summer and winter, in the length group $25-30 \mathrm{~cm}$ (Table 5). 


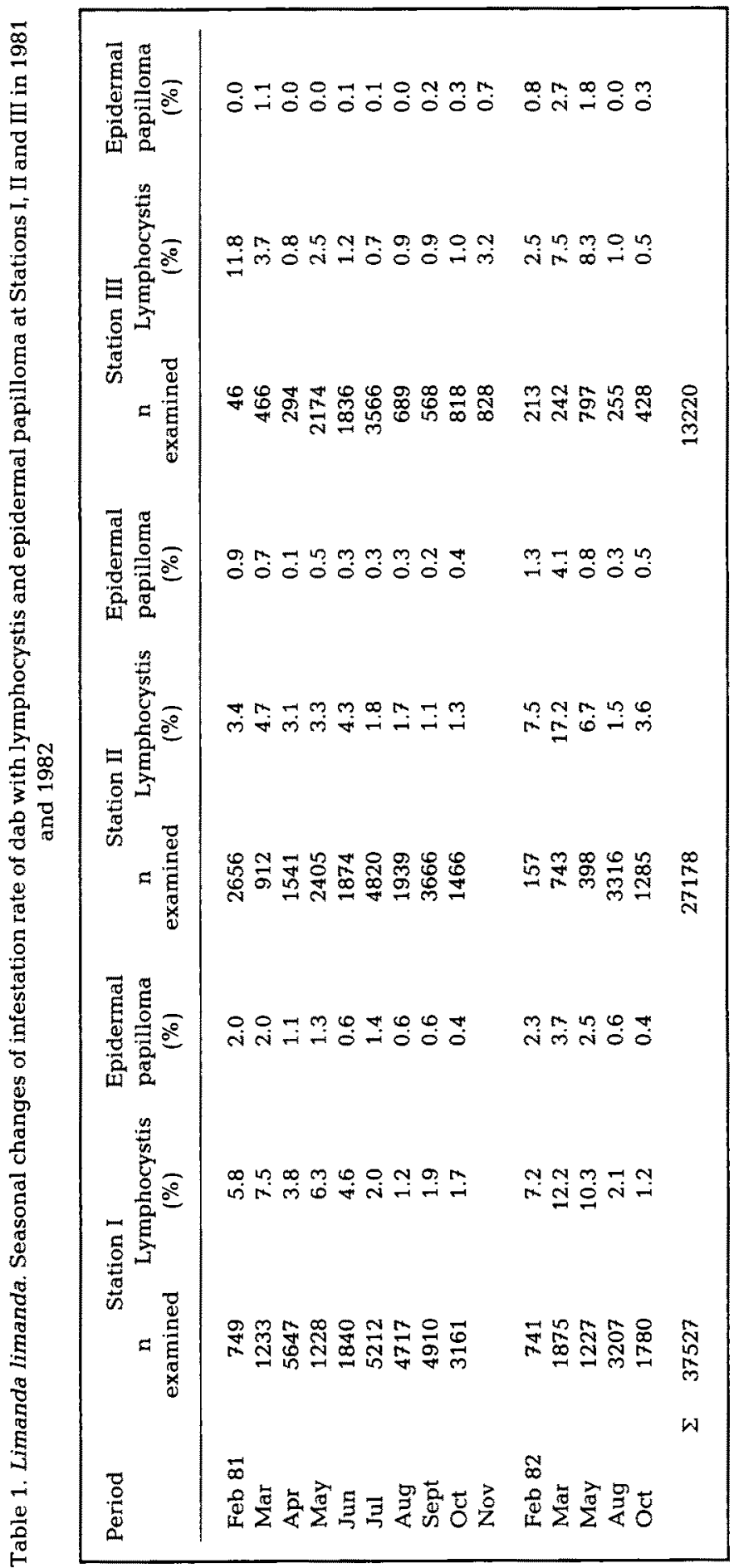


Table 2. Limanda limanda. Classified intensity of lymphocystis (\%) in March, May, August and October 1982 at Stations I, II and III. For classification scheme see text

\begin{tabular}{|c|c|c|c|c|c|c|c|c|c|}
\hline Station & Intensity & March & $\mathbf{n}$ & May & $\mathbf{n}$ & August & $\mathbf{n}$ & October & $n$ \\
\hline \multirow[t]{3}{*}{1} & A & 7.5 & 280 & 11.4 & 158 & 13.6 & 44 & 21.4 & 28 \\
\hline & $\mathrm{B}$ & 48.2 & & 54.4 & & 61.3 & & 71.4 & \\
\hline & $\mathrm{C}$ & 44.3 & & 34.1 & & 25.0 & & 7.1 & \\
\hline \multirow[t]{3}{*}{ II } & A & 15.3 & 150 & 24.1 & 29 & 25.0 & 28 & 36.1 & 36 \\
\hline & B & 45.3 & & 51.7 & & 57.1 & & 61.1 & \\
\hline & C & 39.3 & & 24.1 & & 17.8 & & 2.8 & \\
\hline \multirow[t]{3}{*}{ III } & A & 15.0 & 20 & 13.8 & 101 & 33.3 & 6 & 28.5 & 7 \\
\hline & $B$ & 40.0 & & 40.5 & & & & 57.1 & \\
\hline & $\mathrm{C}$ & 45.0 & & 45.5 & & 66.6 & & 14.2 & \\
\hline
\end{tabular}

Table 3. Limanda limanda. Classified intensity of epidermal papilloma (\%) in dab from February to May and in August and October 1982 at Stations I and II. For classification scheme see text

\begin{tabular}{|c|c|c|c|c|c|c|}
\hline Station & & nsity & February-May 1982 & $\mathrm{n}$ & August + Oct 1982 & $\mathbf{n}$ \\
\hline \multirow[t]{4}{*}{ I } & A & $<0.5$ & 72.7 & 128 & 71.4 & 21 \\
\hline & $\mathrm{B}$ & $0.5-1$ & 10.2 & & 19.0 & \\
\hline & $\mathrm{C}$ & $1.0-1.5$ & 7.8 & & 4.8 & \\
\hline & $\mathrm{D}$ & $>1.5$ & 9.4 & & 4.8 & \\
\hline \multirow[t]{4}{*}{ II } & A & $<0.5$ & 78.9 & 38 & 63.6 & 11 \\
\hline & B & $0.5-1$ & 13.2 & & 36.4 & \\
\hline & $\mathrm{C}$ & $1.0-1.5$ & 5.3 & & & \\
\hline & $\mathrm{D}$ & $>1.5$ & 2.6 & & & \\
\hline
\end{tabular}

\section{Summary of statistics}

The significance of positive correlations between season, area, population density and infestation rates of lymphocystis and epidermal papillomas was tested by using likelihoods (Table 6). The results revealed a highly significant influence of length for both diseases ( $p<0.01 \%$ ). During the spawning season (Feb-Jun), infestation rates of both diseases were significantly higher than in summer $(p<0.01 \%)$. During this time the influence of the area was significant for both lymphocystis and epidermal papillomas $(p<0.01 \%)$. Population density had no significant influence on infestation rates in both diseases.

\section{DISCUSSION}

For both diseases under consideration I found significant differences in infestation rates among hauls and stations. This might indicate the presence of patchiness which is possibly related to spatial segregation of healthy and diseased dab. Spatial segregation of skeletal-deformed and healthy cod in the Elbe Estuary has recently been mentioned 
Table 4. Limanda limanda. Infestation rate of lymphocystis and epidermal papilloma in $9+$ per cm class in the periods February to June and July to October 1981 at Station I

\begin{tabular}{|c|c|c|c|c|c|c|}
\hline $\begin{array}{l}\text { Length } \\
(\mathrm{cm})\end{array}$ & $\begin{array}{c}\text { February-June } \\
1981 \\
\text { n examined }\end{array}$ & $\begin{array}{l}\text { Lympho- } \\
\text { cystis } \\
(\%)\end{array}$ & $\begin{array}{l}\text { Epidermal } \\
\text { papilloma } \\
(\%)\end{array}$ & $\begin{array}{c}\text { July-October } \\
1981 \\
\text { n examined }\end{array}$ & $\begin{array}{l}\text { Lympho- } \\
\text { cystis } \\
(\%)\end{array}$ & $\begin{array}{c}\text { Epidermal } \\
\text { papilloma } \\
(\%)\end{array}$ \\
\hline 13 & & & & 45 & 2.2 & \\
\hline 14 & 91 & 1.1 & & & & \\
\hline 15 & 181 & 1.7 & & 301 & 0.7 & \\
\hline 16 & 299 & 1.3 & & 664 & 0.3 & \\
\hline 17 & 456 & 1.1 & 0.4 & 1156 & 0.5 & \\
\hline 18 & 470 & 2.8 & 1.1 & 1384 & 0.5 & 0.2 \\
\hline 19 & 498 & 2.6 & 1.8 & 1413 & 0.8 & 0.3 \\
\hline 20 & 694 & 3.6 & 1.7 & 1446 & 1.7 & 0.7 \\
\hline 21 & 541 & 4.8 & 1.3 & 955 & 1.3 & 0.5 \\
\hline 22 & 516 & 5.2 & 1.9 & 835 & 2.3 & 0.8 \\
\hline 23 & 366 & 7.4 & 2.5 & 488 & 2.5 & 1.6 \\
\hline 24 & 300 & 5.0 & 3.0 & 332 & & 1.2 \\
\hline 25 & 252 & 5.2 & 4.8 & 221 & 6.3 & 1.8 \\
\hline 26 & 146 & 6.2 & 2.7 & 105 & 3.8 & 2.9 \\
\hline 27 & 107 & 7.5 & 1.9 & 74 & 4.1 & 4.1 \\
\hline 28 & 67 & 3.0 & 1.5 & 57 & 3.5 & 1.8 \\
\hline 29 & 39 & 5.1 & 2.6 & 35 & 8.6 & 2.9 \\
\hline 30 & 21 & 14.3 & 4.8 & 14 & & 14.3 \\
\hline 31 & 2 & & & 5 & 20.0 & \\
\hline 32 & 5 & 33.3 & & 8 & & \\
\hline 33 & & & & 3 & & \\
\hline$\Sigma$ & 5051 & & & 9514 & & \\
\hline
\end{tabular}

Table 5. Limanda limanda. Infestation rates in Winter 1982

\begin{tabular}{|c|c|c|c|c|}
\hline Disease & Length $(\mathrm{cm})$ & Age (years) & Sex & $\begin{array}{c}\text { Max. infestation } \\
\text { rate }(\%)\end{array}$ \\
\hline Lymphocystis & $\begin{array}{l}18-19 \\
21-23 \\
25-27\end{array}$ & $\begin{array}{r}4 \\
5-6 \\
8-10\end{array}$ & $\begin{array}{l}80 \\
00 \\
90\end{array}$ & $\begin{array}{l}22.0 \\
30.5 \\
37.0\end{array}$ \\
\hline $\begin{array}{l}\text { Epidermal } \\
\text { papilloma }\end{array}$ & $\begin{array}{r}21-22 \\
25 \\
27-30\end{array}$ & $\begin{array}{r}5-6 \\
8 \\
>10\end{array}$ & $\begin{array}{l}\not d \\
q q \\
q 9\end{array}$ & $\begin{array}{l}11.1 \\
13.8 \\
20.0\end{array}$ \\
\hline
\end{tabular}

by Möller (1983). Significant sources of variance were identified during preceeding studies. They resulted mainly in haul-to-haul variability, and in differences in accuracy between different investigators (Dethlefsen et al., 1983). I tried to minimize this variability by considering only up to 6 pooled hauls per station. Therefore, $I$ assume that the differences encountered were not mainly due to the methods applied but due to differences in behaviour of the fish. Further investigation of dab behaviour is needed to 
Table 6. Limanda limanda. Overall statistical comparison of influences of length, month, area and population density on differences in infestation rates of lymphocystis and epidermal papilloma compared by quotients of likelihood

\begin{tabular}{|c|c|c|c|c|c|c|c|}
\hline Disease & $\begin{array}{l}\text { Test on } \\
\text { influence } \\
\text { of }\end{array}$ & Sex & $\begin{array}{l}\text { Degree } \\
\text { of } \\
\text { freedom }\end{array}$ & $\begin{array}{l}\text { Likelihood } \\
\text { quotient }\end{array}$ & $P$ & $\begin{array}{c}\text { Mantel- } \\
\text { Haenszel } \\
\text { statistic }\end{array}$ & $\mathbf{P}$ \\
\hline \multirow[t]{4}{*}{ Lymphocystis } & Length & $\begin{array}{l}q \\
\sigma\end{array}$ & $\begin{array}{l}5 \\
5\end{array}$ & $\begin{array}{l}394.63 \\
370.88\end{array}$ & $\begin{array}{l}0.000 \\
0.000\end{array}$ & & \\
\hline & Months & $\begin{array}{l}q \\
\delta\end{array}$ & $\begin{array}{l}14 \\
14\end{array}$ & $\begin{array}{l}354.99 \\
440.86\end{array}$ & $\begin{array}{l}0.000 \\
0.000\end{array}$ & & \\
\hline & Area & $\begin{array}{l}q \\
0\end{array}$ & $\begin{array}{l}3 \\
3\end{array}$ & $\begin{array}{l}30.97 \\
65.61\end{array}$ & $\begin{array}{l}0.000 \\
0.000\end{array}$ & $\begin{array}{l}30.52 \\
61.05\end{array}$ & $\begin{array}{l}0.0 \\
0.0\end{array}$ \\
\hline & Population & $\begin{array}{l}q \\
\delta\end{array}$ & $\begin{array}{l}1 \\
1\end{array}$ & $\begin{array}{l}3.17 \\
0.23\end{array}$ & $\begin{array}{l}0.075 \\
0.632\end{array}$ & & \\
\hline \multirow[t]{4}{*}{$\begin{array}{l}\text { Epidermal } \\
\text { papilloma }\end{array}$} & Length & $\begin{array}{l}q \\
\delta\end{array}$ & $\begin{array}{l}5 \\
4\end{array}$ & $\begin{array}{l}209.52 \\
107.09\end{array}$ & $\begin{array}{l}0.000 \\
0.000\end{array}$ & & \\
\hline & Months & $\begin{array}{l}q \\
0\end{array}$ & $\begin{array}{l}14 \\
14\end{array}$ & $\begin{array}{r}171.37 \\
86.08\end{array}$ & $\begin{array}{l}0.000 \\
0.000\end{array}$ & & \\
\hline & Area & $\begin{array}{l}q \\
0\end{array}$ & $\begin{array}{l}3 \\
3\end{array}$ & $\begin{array}{l}31.13 \\
15.60\end{array}$ & $\begin{array}{l}0.000 \\
0.001\end{array}$ & $\begin{array}{l}60.55 \\
22.97\end{array}$ & $\begin{array}{l}0.0 \\
0.0\end{array}$ \\
\hline & Population & $\begin{array}{l}q \\
d\end{array}$ & $\begin{array}{l}1 \\
1\end{array}$ & $\begin{array}{l}0.58 \\
0.00\end{array}$ & $\begin{array}{l}0.446 \\
1.000\end{array}$ & & \\
\hline
\end{tabular}

Table 7. Limanda limanda. Variability of infestation rates of lymphocystis and epidermal papilloma between hauls

\begin{tabular}{|lcccc|}
\hline Date & Station & Haul No. & No. of fish & Infestation rate (\%) \\
\hline & & & & Lymphocystis \\
March 1982 & I & 1 and 4 & $279-237$ & $21.5-10.1$ \\
May 1982 & I & 2 and 6 & $235-267$ & $16.6-10.1$ \\
May 1981 & II & 1 and 5 & $573-540$ & $1.2-3.5$ \\
Sept. 1981 & II & 3 and 6 & $382-392$ & $2.4-0.8$ \\
Feb. 1981 & III & 1 and 2 & $78-78$ & $8.9-1.2$ \\
& & & & Epidermal papilloma \\
Feb. 1981 & & & & $3.8-2.6$ \\
Feb. 1982 & I & 1 and 2 & $78-78$ & $0.6-3.4$ \\
March 1981 & II & 4 and 6 & $159-148$ & $1.2-0$ \\
Oct. 1982 & II & 1 and 3 & $249-252$ & $0.8-1.7$ \\
Aug. 1982 & I & 3 and 6 & $119-116$ & $0.8-0$ \\
\hline
\end{tabular}

fill this gap in our knowledge. Table 7 shows that significant differences in infestation rates between 2 hauls in the same area might be obtained even if the numbers of fish caught were comparable but not large enough for a reliable estimation.

Considering the stations trawled during this survey, dab were most abundant in the 
dumping area northwest of the island of Helgoland. A possible explanation for this fact is that sandy bottom prevails in this area, and water depths range from 25 to $28 \mathrm{~m}$. There are some hints in literature that dab prefer a sandy bottom and depths of 15 to $40 \mathrm{~m}$ (Ortega-Salas, 1980; Möller Christensen, 1977; Terofal, 1978). Furthermore, this area is considered to be a major spawning place of dab (Aurich, 1941; Bohl, 1957). Only for a short period were dab most abundant at Station III, southeast of Helgoland. This station is characterized by muddy sediments and higher food density as compared to the dumping area (Stripp \& Gerlach, 1969; Salzwedel et al., in press). In February 1981, most dab were caught at Station II. In 1981 and 1982, females dominated at Station III. This was possibly due to differences in behaviour between males and females (Bohl, 1957).

My investigation indicates that migrations of dab may occur throughout the year. This is not in agreement with Bohl (1957), who suggests seasonal migrations of dab. Lee (1972) showed that distances migrated by dab on the British coast were within the 20 to $30 \mathrm{~km}$ range, but his results are based on only 70 recaptured dabs.

The changes in length distribution required infestation rates to be related to a population of standardized size for comparison. Length and infestation rates of dab with lymphocystis and epidermal papilloma tumed out to be positively correlated. Such relation has also been described by Möller (1983) for fish from that region. Infestation rates of dab with lymphocystis and epidermal papilloma increased steeply in February of both years under survey. Maximum rates were reached in March and May of both years. According to Bohl (1957), dab spawn in the German Bight mainly from March to May. Several authors found lowest condition factors of dab during this time (Bohl, 1957; Lee, 1972; Ortega-Salas, 1980).

The relation between high infestation rates and stress like spawning or poor condition factor has been described by many authors. Amin (1979), for example, found maximum lymphocystis rates in walleye during spawning; Weissenberg (1938) observed the same for orange file fish Aleutera schoephii, and Vitinsh \& Baranova (1976) for the flounder. On the other hand, Mann (1970) reported from the North Sea that - according to reports of fishermen - percentages of fishes afflicted with lymphocystis were higher in summer. The outbreak of the diseases under survey was recorded well before the beginning of the main spawning season.

Therefore, exhaustion of fish by spawning may not be the only factor responsible for increased infestation rates during this period. In general, it is poor environmental conditions that render fish more susceptible to disease. Thus Peters (1981) supposes that oxygen deficiencies, repeatedly occurring in the lower Elbe during summer, could be responsible for higher infestation rates of eels suffering from cauliflower disease. According to Möller (1983), salinity stress in estuaries may render flounder more susceptible to disease. In experiments and aquaculture, population density constitutes another important factor in transmitting diseases. Thus Perlmutter et al. (1973) demonstrated a depression of the immune factor to IPN virus in blue gourami Trichogaster trichopterus due to overcrowding. There are also some indications that chemical pollution may contribute to the outbreak of certain diseases (e.g. Dethlefsen, 1979; Dethlefsen \& Waterman, 1980).

Maximum disease frequencies were encountered during periods of low water temperature. Mitotic activities of epidermis and tumours of Pleuronectidae and other fishes were high at low water temperatures (Kranz, 1980). Low water temperatures can 
also suppress the immune system, as can "several pollutional factors" (Ellis, 1982). My results show higher infestation rates for both diseases in 1982 as compared to 1981. In the winter of 1982, the water temperatures were much lower than in 1981.

At times of maximum infestation, the intensity of the two diseases under investigation was also highest. During summer, lymphocystis was present in lowest intensities. This is not in agreement with data reported by Russell (1974) who found higher intensities of lymphocystis in plaice in October and lower intensities during summer. The same pattern was observed by Anders (1983) for flounder in the western Baltic Sea. Here we must keep in mind that flounders, plaice and dab harbour different strains of lymphocystis viruses (Anders, 1983).

In dab, main infection by lymphocystis seems to occur during summer, possibly favoured by high population density. The same seems to be true for epidermal papilloma for which infection has not yet been proven.

One to three weeks after infection by lymphocystis, nodules appear on the fish involved (Weissenberg, 1945; Anders, 1983). Latent infection might become apparent under unfavourable environmental conditions and physiological stress (Peters, 1981). After 7 to 9 months, lymphocystis cells are mature and there is no further growth (Schäperclaus, 1979). Some of the diseased dab will die, or the disease will disappear (Vitinsh \& Baranova, 1976). If this general scheme of infection with lymphocystis during summer was correct, we should find increased numbers of fishes infected with lymphocystis in offshore waters during the winter, where dab occur at periods with low water temperature (Bohl, 1957). To test this, I performed bottom trawls in a far offshore area ("Weiße Bank") in February 1982 and found high infestation rates of dab with lymphocystis as well as a high intensity of the disease. The same results were obtained for epidermal papilloma. However, it must be kept in mind that the material at hand is only of limited value for making regional comparisons.

For the rapid decline of tumour rates, either regression of tumours, spatial segregation or mortality (Campana, 1983) might be responsible. Histological investigations revealed that tumour regression, well documented in papillomatosis of eel (Peters \& Peters, 1979), did not occur in our material (Watermann, pers. comm.). Own laboratory experiments, however, showed greater mortality in diseased rather than in healthy fish.

As already mentioned, the causative agent for epidermal papilloma in dab is unknown. Due to similarities in the seasonal cycle of macroscopical appearance, some authors suppose that papilloma might also be caused by viruses. For example, Wellings et al. (1977) assumed that epidermal papilloma in fishes of the Bering Sea is caused by virus. On the other hand, Watermann described the histology of papilloma of dab, taken from the German Bight (Dethlefsen \& Watermann, 1980) and found differences from papilloma described by Wellings et al. (1977). According to Dethlefsen (1984), no virus particles have so far been identified by electronmicroscopical investigations of epidermal papilloma in Limanda limanda. For lymphocystis it has been shown that otherwise healthy fish will become readily infected by the virus if the fish has epidermal lesions or abrasions (Wolf, 1982; Templeman, 1965).

During winter, higher infestation rates of dab with lymphocystis were found at Station I (dumping area) compared with infection rates from other areas. No differences in infestation rates were found in summer. For epidermal papilloma, generally higher infestation rates were encountered at Station I during the whole period of investigation. 
This finding confirms results by Dethlefsen et al. (1980) that higher numbers of fishes with epidermal papilloma were detected in the dumping area than at other stations. Whether or not a causal relation exists between dumping and increased abundances of diseased dab in this area, was not a question to be answered in this study.

\section{CONCLUSIONS}

(1) Dab are infected by lymphocystis mainly during summer. (2) Similarities between lymphocystis and epidermal papilloma suggest that principal infection by epidermal papilloma also occurs in summer. The same seasonalities in both diseases suggest that a virus may act as causative agent of epidermal papillomas in dab, although Dethlefsen et al. (1983) failed to find virus particles. (3) A highly significant positive correlation exists between environmental factors and areas with fish suffering from the two diseases. (4) In order to test a possible negative influence of the dumping of acid-iron wastes, it is necessary to investigate other main spawning areas of dab. It is also necessary to observe the prevalence of both diseases in the dumping area after dumping has been discontinued for several years. (5) The great variability among hauls at the same site requires several hauls be made per area in order to assess the distribution of fish diseases. (6) The influence of body length on infestation rate necessitates relating the results obtained to standardized population (for proper comparison). (7) In order to be able to use dab as an indicator of local pollution, the biology and behaviour of dab must be more thoroughly investigated.

\section{LITERATURE CITED}

Amin, O. M, 1979. Lymphocystis disease in Wisconsin fishes. - J. Fish Dis. 2, $207-217$.

Anders, K., 1983. Statistische, mikroskopische und virologische Untersuchungen zur LymphocystisKrankheit von Knochenfischen der Elbe, Nord- und Ostsee. Dipl.-Arb., Univ. Kiel, 125 pp.

Aurich, H. J., 1941. Die Verbreitung der pelagischen Fischbrut in der südlichen Nordsee (Pleuronectes limanda, Kliesche). - Helgoländer wiss. Meeresunters. 2, 210-211.

Bishop, M. M., Fienberg, S. \& Holland, P. W., 1975. Discrete multivariate analysis. MIT Press, Cambridge, 557 pp.

Bohl, H, 1957. Die Biologie der Kliesche (Limanda limanda) in der Nordsee. - Ber. dt. wiss. Kommn Meeresforsch. 15, 1-57.

Campana, S. E., 1983. Mortality of starry flounders (Platichthys stellatus) with skin tumors. - Can. J. Fish, aquat. Sci. 40, 200-207.

Dethlefsen, V., 1979. Häufigkeit und Vorkommen von Fischkrankheiten und deren mögliche Beziehungen zur Verschmutzung der Deutschen Bucht. - Arb. dt. FischVerb. 27, 169-183.

Dethlefsen, V., 1984. Diseases in North Sea fishes. - Helgoländer Meeresunters. 37, $353-374$.

Dethlefsen, V. \& Watermann, B, 1980. Observations on fish diseases in German Bight and their possible relation to pollution. - Rapp. P.-v. Réun. Cons. perm. int. Explor. Mer 179, 110-117.

Dethlefsen, V., Watermann, B. \& Hoppenheit, M., 1983. Sources of variance in data from fish disease surveys. - C.M./ICES E 2, 1-20.

Ellis, A. E., 1982. Differences between the immune mechanisms of fish and higher vertebrates. In: Microbial diseases of fish. Ed. by R. J. Roberts. Acad. Press, London, 305 pp.

Kranz, H., 1980. Proliferationskinetische Untersuchungen an der normalen und der papillomatös entarteten Fischepidermis. Diss. Univ. Hamburg, 126 pp.

Lee, C. K. C., 1972. The biology and population dynamics of the common dab (Limanda limanda L.) in the North Sea. PhD thesis, Univ. of East Anglia, $104 \mathrm{pp}$.

Lindner, A. \& Berchtold, W., 1976. Statistische Auswertung von Prozentzahlen. Birkhäuser, Basel, $290 \mathrm{pp}$. 
Mann, H., 1970. Uber den Befall der Plattfische in der Nordsee mit Lymphocystis. - Ber. dt. wiss. Kommn Meeresforsch. 21, 219-223.

Möller, H., 1981. Fish diseases in German and Danish coastal waters in summer 1980. - Meeresforschung 29, 1-16.

Möller, H., 1983. Seasonal and regional fluctuations of fish diseases in the Elbe estuary - C.M./ICES E 47 .

Möller Christensen, J, 1977. Die Fische der Nordsee. Franckh, Stuttgart, 128 pp.

Ortega-Salas, A. A., 1980. Seasonal changes in the common dab (Limanda limanda L.) in Isle of Man waters. - J. Fish Biol. 16, 75-82.

Perlmutter, A., Sarat, D. A., Yu, M.-L., Filazzola, R. J. \& Seeley, R. J, 1973. The effects of crowding on the immune response of the blue gourami (Trichogaster trichopterus) to infectious pancreatic necrosis (IPN) virus. - Life Sci. 13, 363-375.

Peters, G. \& Peters, N., 1979. The influence of salinity on growth and structure of epidermal papillomas of the European eel (Anguilla anguilla L.) - J. Fish Dis. 2, 13-26.

Peters, N, 1981. Fischkrankheiten und Gewässerbelastung im Küstenbereich, - Verh. dt. zool. Ges. $74,16-30$.

Russell, P. H., 1974. Lymphocystis in wild plaice (Pleuronectes platessa L.) and flounder (Platichthys flesus L.) in British coastal waters: A histopathological and serological study. - J. Fish Biol. 6, $771-778$.

Salzwedel, H., Rachor, E. \& Gerdes, D., 1984. Benthic macrofauna communities in German Bight. Veröff. Inst. Meeresforsch. Bremerh. (In press.)

Schäperclaus, W., 1979. Fischkrankheiten. Akademie Verl., Berlin, 1089 pp.

Sindermann, C. J, 1980. The role and value of pathobiology in pollution effects monitoring programs. - Rapp. P.-v. Réun. Cons. int. perm. Explor. Mer 179, 135-151.

Stripp, K. \& Gerlach, S. A., 1969. Die Bodenfauna im Verklappungsgebiet von Industrieabwässern nordwestlich von Helgoland. - Veröff. Inst. Meeresforsch. Bremerh. 12, 149-156.

Templeman, W., 1965. Lymphocystis disease in American plaice of the eastern Grand Bank. - J. Fish. Res. Bd Can. 22, 1345-1356.

Terofal, F., 1978. Fische. BLV Verl. Ges, München, 143 pp.

Vitinsh, M. \& Baranova, T., 1976. Lymphocystis disease of Baltic flounder (Platichthys flesus L.).C.M./ICES $P 16$.

Weissenberg, R., 1938. Studies on virus diseases of fish. I. Lymphocystis disease of the orange file fish (Aleutera schoepfii). - Am. J. Hyg. 28, 455-462.

Weissenberg, R., 1945. Studies on virus diseases of fish. IV. Lymphocystis disease in Centrarchidae. - Zoologica, N. Y. 30, 169-184.

Wellings, S. R., Alpers, Ch. E., McCain, B. B. \& Myers, M. S., 1977. Fish disease in the Bering Sea. Ann. N. Y. Acad. Sci. 298, 290-304.

Wolf, K., 1962. Experimental propagation of lymphocystis disease of fishes. - Virology 18, 249-256. 